\title{
GMR
}

\section{Tissue culture characteristics of maize (Zea mays L.) haploid coleoptile sections}

\author{
L. Jiang*, G.X. Jing*, X.Y. Li, X.Q. Wang, Z. Xing, P.K. Deng and R.G. Zhao \\ School of Agronomy, Jilin Agriculture University, Changchun, Jilin Province, China \\ *These authors contributed equally to this study. \\ Corresponding author: R.G. Zhao \\ E-mail: jianglong335@sina.com
}

Genet. Mol. Res. 14 (4): 16265-16275 (2015)

Received June 12, 2015

Accepted September 2, 2015

Published December 8, 2015

DOI http://dx.doi.org/10.4238/2015.December.8.17

\begin{abstract}
Doubled haploid (DH) technology, which is used for rapidly purifying genetic resources, is a key technology in modern maize breeding. The present study evaluated the tissue culture characteristics of maize haploid coleoptile sections, in order to provide a new way of haploid doubling. With 20 combinations of haploid coleoptile sections, obtained by hybridization within Reid, Tangsipingtou, and Term-tropical groups, as explants, we analyzed the induction and differentiation rate of callus, observed the number of root tip chromosomes in regenerated plants, and analyzed the pollen fertility. In addition, we used 47 SSR markers to analyze the genotypes of regenerated plants. The Reid and Tangsipingtou groups had significantly higher induction rates of haploid coleoptile callus compared to the Term-tropical group. Fifteen haploid plants were obtained which had 10 chromosomes in the root tips as assessed by I-KI staining. It was also noticed that the pollen of pollinated anthers were partially fertile. The haploid plants had genetic stability and showed no variation. The Reid and Tangsipingtou groups had good culture characteristics of haploid coleoptile sections, while the Term-tropical group had poor culture characteristics. Genotypes of haploid plants generated by tissue culture were evidenced to come
\end{abstract}


from recombinant types of parents. Thus, this study established a tissue culture system of maize haploid coleoptile.

Key words: Coleoptile sections; Haploid; Tissue culture; Zea mays L.

\section{INTRODUCTION}

Maize (Zea mays L.) is one of the world's most valuable crops being an important source of food, fodder and materials of industrial use. Characterized by high yield and adaptability to a variety of conditions, maize is preferred over other crops for planting in many countries (Geiger and Gordillo, 2009). To meet the future demand for maize and of maize-based industries, the production of the crop needs to be increased. This can be achieved through two important ways, namely resource-conserving cropping system and use of improved crop varieties. Under modern agricultural conditions, peasants often choose two maize varieties namely hybrid variety and open pollination variety (OPV); their choice relying more on the prevailing environmental and economy conditions as well as the availability of right varieties for purchase (Pixley and Banziger, 2004). Hybrids of two mutually independent homozygous inbred lines are more widely used. Most of the world's commercial maize varieties come from the hybridization of two or more inbred or pure lines. Usually, breeding of homozygous inbred lines requires continuous inbreeding for 6-10 generations, which requires 3-5 years on the premise of two assured generations per year (Hallauer et al., 2010).

With climate change and growing population, effective breeding strategies can optimize the selection of breeding materials for each generation to a maximum degree. Among the methods of maize haploid breeding and recurrent selection, biological induction of haploids is the most effective one (Röber et al., 2005; Gallais and Bordes, 2007). By inducing the generation of haploid and double haploid chromosome sets, pure lines (doubled haploid (DH) lines) can be obtained in only two generations, thereby, accelerating the progress of variety improvement. There are two traditional methods for obtaining fertile haploids: the spontaneous haploid doubling, for which doubling rates ranging from 0 to $21.4 \%$ have been reported in various maize genotypes (Chase, 1952; Barnabas et al., 1999; Han et al., 2009; Jiang et al., 2014) and the artificial chromosome doubling, which can duplicate the chromosome set of haploid plants effectively using doubling agents (Häntzschel and Weber, 2010; Wu et al., 2014). DH lines have been widely used in many fields of breeding and research (Presterl et al., 2007; Wilde et al., 2010; Martin et al., 2011).

$\mathrm{DH}$ plants can be obtained by treating microspore, anther, haploid callus, haploid stem tip or haploid young embryos with colchicine or herbicides. However, due to genotypic limitation, breeding of maize microspore and anther has a long culture cycle and a low differentiation rate. Besides, doubling technologies of haploid stem tip and young embryos are under patent protection. Treatment of 6-leafed haploid maize plants with $\mathrm{N}_{2} \mathrm{O}$ induced $44 \%$ haploid plants to inbreed and set seed (Kato and Geiger, 2002); this doubling strategy is, however, not feasible in field breeding. At present, type-I callus can be successfully induced using maize coleoptile sections as explants (Soriano et al., 2007), but to the best of our knowledge tissue culture of haploid coleoptile sections has not been attempted culture characteristics of these explants from heterotic groups have not been reported from China or abroad. The present study was, therefore, undertaken to analyze the induction and differentiation rate of callus produced from 20 combinations of haploid coleoptiles obtained by hybridization of maize groups Reid, Tangsipingtou, and Term-tropical. The tissue culture characteristics of the haploid coleoptiles were also studied with an aim of devising a feasible method for maize haploid breeding. 


\section{MATERIAL AND METHODS}

\section{Plant materials}

JAAS3 was used as the haploid inducer line (Cai et al., 2007). Twenty $F_{1}$ hybrids were generated from inbred lines of Reid, Tangsiptou, and Term-tropical groups, based on the principle of combination within heterotic groups (Table 1), and along with haploid inducer lines, they were allocated and planted in Changchun Breeding Base of Jilin Agricultural University in June 2014.

Table 1. Material list of 20 hybrids and their parents.

\begin{tabular}{ll}
\hline Group & Materials \\
\hline Reid & C8605-2/Zheng58, Zheng58/7922, X73/Zheng58, Shen5003/1216, Shen5003/9137, Zheng58/B73, \\
& Shen5003/Dan9046, C8065-2/Liao8160 \\
Tangsipingtou & 444/482, Chang7-2/Dan5026, Ji854/Chang7-2, Ji853/LX9801, Ji853/Hangzao4, 482/Chang7-2 \\
Term-tropical & P178/Dan599, Shen137/Dan599, Qi319/Dan599, P178/Dan988, P178/Qi319, Shen137/P178 \\
\hline
\end{tabular}

\section{Medium composition}

Five different culture medium, namely MSVS34 germination medium (Sidorov et al., 2006), MSW57 induction medium (Sidorov et al., 2006), N6 subculture medium, and differentiation and rooting medium, were used in the experiment. Components of each medium were as follows: MSVS34 germination medium: Murashige and Skoog's (MS) macroelements, microelements, and organic matter, $40 \mathrm{~g} / \mathrm{L}$ maltose, $0.1 \mathrm{~g} / \mathrm{L}$ casein hydrolysate, $1.95 \mathrm{~g} / \mathrm{L} \mathrm{MES}, 0.75 \mathrm{~g} / \mathrm{L}$ magnesium chloride, $0.5 \mathrm{~g} / \mathrm{L}$ glutamine, $0.1 \mathrm{~g} / \mathrm{L}$ ascorbic acid, $10 \mathrm{mg} / \mathrm{L}$ picloram, $3 \mathrm{mg} / \mathrm{L} \mathrm{BAP}$, and $8 \mathrm{~g} / \mathrm{L}$ agar, pH 5.8; MSW57 induction medium: MS macroelements, microelements, and organic matter, 0.5 $\mathrm{mg} / \mathrm{L}$ thiamine hydrochloride, $0.5 \mathrm{~g} / \mathrm{L}$ casamino acid, $30 \mathrm{~g} / \mathrm{L}$ sucrose, $1.38 \mathrm{~g} / \mathrm{L}$ proline, $3.4 \mathrm{mg} / \mathrm{L}$ silver nitrate, $0.5 \mathrm{mg} / \mathrm{L}$ 2,4-dichlorophenoxyacetic acid (2,4-D), $2.2 \mathrm{mg} / \mathrm{L}$ picloram, $8 \mathrm{~g} / \mathrm{L}$ agar, $\mathrm{pH}$ 5.8; N6 subculture medium: N6 macroelements, microelements, and organic matter, $0.5 \mathrm{~g} / \mathrm{L}$ casein hydrolysate, $0.7 \mathrm{~g} / \mathrm{L}$ proline, $2 \mathrm{mg} / \mathrm{L}$ 2,4-D, $30 \mathrm{~g} / \mathrm{L}$ sucrose, $2.7 \mathrm{~g} / \mathrm{L}$ gelatin, $\mathrm{pH} 5.8$; Differentiation medium: MS macroelements, microelements and organic matter, $100 \mathrm{mg} / \mathrm{L}$ inositol, $0.5 \mathrm{~g} / \mathrm{L}$ proline, $0.5 \mathrm{~g} / \mathrm{L}$ casein hydrolysate, $250 \mathrm{mg} / \mathrm{L}$ glutamine, $25 \mathrm{mg} / \mathrm{L}$ succinic acid, $30 \mathrm{~g} / \mathrm{L}$ sucrose, $3.0 \mathrm{~g} / \mathrm{L}$ gelatin, pH 5.8; Rooting medium: MS macroelements, microelements and organic matter, $0.5 \mathrm{mg} / \mathrm{L}$ 1-Naphthaleneacetic acid (NAA), $30 \mathrm{~g} / \mathrm{L}$ sucrose, $1.2 \mathrm{~g} / \mathrm{L}$ gelatin, $\mathrm{pH} 5.8$.

\section{Simple sequence repeat (SSR) primers}

Primers from Maize Genetics and Genomics Database (MaizeGDB; http://www. maizeGDB.org) were selected so as to uniformly cover the whole maize genome. The primers were synthesized by Beijing Augct Biotechnology Limited Liability Company (Beijing, China, http://www. augct.com). For genomic analysis of the haploid plants, 47 pairs of SSR primers were selected. The names and genomic locations of primers are provided in Table 2.

\section{Grain treatment}

Twenty $F_{1}$ hybrids used as female parents were hybridized with haploid inducer lines. After seeds matured and dried, 100 grains with purple top and white embryo were selected from 
each plant, placed into envelopes, and dried in an incubator with the envelope mouths open. A 250-mL beaker was filled with $200 \mathrm{~mL} 5.25 \%$ sodium hypochlorite solution and $2 \mathrm{~mL}$ concentrated hydrochloric acid was added to it. Thereafter, the beaker was placed in the middle of a dryer for 8-15 h for closed treatment. Grains were taken out, placed in a beaker, and treated with $70 \%$ ethyl alcohol on a clean bench for $1 \mathrm{~min}$; these grains were soaked in $2 \%$ sodium hypochlorite solution for 20 min after removing the 70\% ethyl alcohol and then washed with sterile water for 4-5 times before soaking in sterile water overnight. Mature embryos were peeled off, inoculated on MSVS34 medium, and cultured for $7-10$ days at $25^{\circ} \mathrm{C}$ under 2000 lux illumination provided $16 \mathrm{~h}$ per day.

\begin{tabular}{|c|c|c|c|c|c|c|c|}
\hline SSR marker & $\begin{array}{l}\text { Genomic } \\
\text { location }\end{array}$ & SSR marker & $\begin{array}{l}\text { Genomic } \\
\text { location }\end{array}$ & SSR marker & $\begin{array}{l}\text { Genomic } \\
\text { location }\end{array}$ & SSR marker & $\begin{array}{l}\text { Genomic } \\
\text { location }\end{array}$ \\
\hline bnlg1017 & 1.12 & bnlg1533 & 3.12 & bnlg2405 & 5.07 & phi080 & 8.08 \\
\hline bnlg449 & 1.13 & phi063 & 3.15 & bnlg151 & 6 & phi2376 & 8.09 \\
\hline umc2122 & 1.14 & umc1146 & 3.2 & bnlg259 & 6.01 & umc2084 & 9.01 \\
\hline umc1345 & 1.16 & phi082 & 4.11 & bnlg1712 & 6.05 & phi065 & 9.03 \\
\hline umc1157 & 1.17 & bnlg491 & 4.14 & phi299852 & 6.07 & umc1493 & 9.04 \\
\hline bnlg1681 & 1.2 & bnlg2297 & 4.16 & umc1545 & 7 & umc1221 & 9.05 \\
\hline bnlg2341 & 1.21 & umc1999 & 4.19 & umc1066 & 7.01 & phi043 & 10.00 \\
\hline phi96110 & 3 & umc1940 & 4.19 & umc1125 & 7.04 & umc1442 & 10.02 \\
\hline umc2017 & 2.14 & umc2118 & 5.02 & phi328175 & 7.04 & bnlg1732 & 10.03 \\
\hline bnlg1950 & 2.18 & umc1705 & 5.03 & phi116 & 7.06 & umc2153 & 10.04 \\
\hline bnlg1530 & 2.19 & umc1422 & 5.03 & bnlg2235 & 8.02 & umc1516 & 10.05 \\
\hline umc2115 & 3.04 & $\mathrm{mmc} 0081$ & 5.05 & umc1741 & 8.03 & & \\
\hline
\end{tabular}

\section{Callus induction from haploid coleoptile section and subculture}

After germination of mature embryos, purple parts of radicle, embryo and germ were removed, while the colorless haploid parts were selected. About $1 \mathrm{~cm}$ coleoptile $(0.5 \mathrm{~cm}$ from the upper and lower stem nodes, respectively) was cut when haploid seedling grew to $5-6 \mathrm{~cm}$; it was equally divided using a scalpel and then inoculated on MSW57 callus induction medium with sections sticking closely to the medium. The culture was performed at $25^{\circ} \mathrm{C}$ under 2000 lux illumination (provided $16 \mathrm{~h}$ per day) for 21 days. Callus induced from coleoptiles was transferred to N6 subculture medium for culture under dark conditions at $25^{\circ} \mathrm{C}$. Subculture was performed every 21 days.

\section{Regeneration and transplantation of haploid plants}

Haploid callus was transferred to differentiation medium and cultured at $25^{\circ} \mathrm{C}$ under 2000 lux illumination (provided $16 \mathrm{~h}$ per day); the regenerated shoots were transferred to rooting medium when they attained a height of 3-5 cm. Plantlets with good roots were transplanted to flowerpots and grown in greenhouse for 7-10 days. The plantlets that survived transplantation were finally planted in the greenhouse.

\section{Observation of the number of chromosomes}

When transplanting regenerated plants to flowerpots, 1-2 root tips were cut and fixed in Carnoy's fluid (absolute ethyl alcohol:glacial acetic acid = 3:1) for over 2 h. After washing with double-distilled water $\left(\mathrm{ddH}_{2} \mathrm{O}\right)$ several times, an appropriate amount of a mixture of cellulase and pectinase was added to the fixed root tips and enzymolysis was performed for $2 \mathrm{~h}$ followed by 
tablet forming. The number of chromosomes in the cut root tips was observed under a microscope and photographed.

\section{lodine-potassium iodide (I-KI) staining of maize pollen}

After heading of regenerated plants, some tassels could be pollinated. The pollinated anther was taken and placed on a glass slide. It was mounted after addition of one drop of $0.2 \%$ $\mathrm{I}-\mathrm{KI}$ solution and was finally observed under a microscope and photographed.

\section{Haploid plant doubling}

Colchicine $(0.05 \%)$ solution was prepared in $1 \%$ detergent. At 4 -leaf and 6 -leaf stage of regenerated plants, a little colchicine solution was dropped on the heartleaf.

\section{DNA extraction from haploid leaves}

Maize genomic DNA was extracted from flag leaves at flowering using the CTAB procedure (Saghai-Maroof et al., 1984). The concentration and quality of DNA was evaluated. The DNA sample was diluted to $10 \mathrm{ng} / \mathrm{\mu L}$ and stored at $4^{\circ} \mathrm{C}$ until further use.

\section{Genotypic analysis of regenerated plants}

Forty-seven pairs of SSR primers were selected for genotypic analysis of regenerated haploid plants. Polymerase chain reaction (PCR) was performed in a $25-\mu \mathrm{L}$ mixture containing 2.5 $\mu \mathrm{L}$ 10X Taq buffer (Transgen Biotech, China), $2 \mu \mathrm{L} 2 \mathrm{mM}$ dNTPs (Transgen Biotech), $0.2 \mu \mathrm{L}$ Taq enzyme (5 $\mathrm{U} / \mu \mathrm{L}$; Transgen Biotech), $1 \mu \mathrm{L}$ forward and reverse primers $(0.1 \mu \mathrm{M}), 5 \mu \mathrm{L}$ template

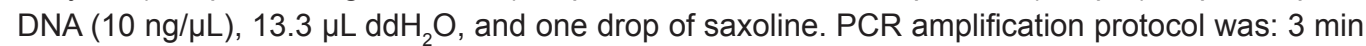
at $95^{\circ} \mathrm{C}$; 35 cycles of $30 \mathrm{~s}$ at $95^{\circ} \mathrm{C}, 30 \mathrm{~s}$ at $60^{\circ} \mathrm{C}$, and $1 \mathrm{~min}$ at $72^{\circ} \mathrm{C} ; 10 \mathrm{~min}$ at $72^{\circ} \mathrm{C}$; and final hold at $4^{\circ} \mathrm{C}$. PCR amplification products were electrophoresed on a $4 \%$ low melting-point agarose gel at $130 \mathrm{~V}$ for $2 \mathrm{~h}$ followed by observation and photography using a gel imaging system.

\section{RESULTS}

\section{Statistics of induction and differentiation rates of callus from haploid coleoptile section}

A total of 610 pieces of callus were obtained from 904 haploid coleoptile sections and 1808 explants. All the pieces of induced callus demonstrated a weak growing trend. Induction and differentiation rates of calli are shown in Table 3.

There was substantial difference in the callus induction rate among the heterotic groups. The Reid group had the highest induction rate ( $41.55 \%)$, followed by Tangsipingtou (39.37\%) and Term-tropical (17.25\%). Moreover, the induction rates differed significantly even within the same heterotic group. In Reid, the maximum induction rate was $76.8 \%$ (Zheng58/B73), while the minimum was only 20.3\% (Shen5003/Dan9046). The induction rates of X73/Zheng58 and Shen5003/9137 were both above $40 \%$, while those of other materials were above $30.0 \%$. In the Tangsipingtou group, Ji854/Chang7-2 had the highest induction rate (65.6\%), followed by Chang7-2/Dan5026 (46.0\%); 
Ji853/LX9801 and Ji853/Huangzao4 had very low induction rates of about 25.0\%; 444/482 and 482/Chang7-2 had induction rates above 30.0\%. Callus induction was poor in materials of Termtropical group with maximum induction rate of only $31.6 \%$ (Shen137/Dan599); the induction rates of other materials being lower than $20 \%$. Evaluation using $t$ test revealed significant differences in haploid coleoptile callus induction rates between the Reid and Term-tropical groups $(P=0.003)$ as well as between the Tangsipingtou and Term-tropical groups $(P=0.04)$. However, no significant difference was observed between Reid and Tangsipingtou groups $(P=0.395$; Table 3$)$.

Differences in haploid callus differentiation rates were noticed among the heterotic groups., Haploid regenerated plants were obtained in the Reid and Tangsipingtou groups (Figure 1A) while no differentiation was observed in the Term-tropical group. In the Reid group, the differentiation rates of Zheng58/B73, Shen5003/1216, Shen5003/9137, and X73/Zheng58 were 14.3, 11.1, 7.3, and $4.5 \%$, respectively. Eighteen haploid plants differentiated in this group, of which 8 survived. In the Tangsipingtou group, differentiation rates of Ji854/Chang7-2 and Chang7-2/Dan5026 were 11.9 and $6.5 \%$, respectively, and 10 haploid plants differentiated, of which 7 survived. No haploid plants differentiated in 6 materials in the Term-tropical group (Table 3).

Table 3. Induction and differentiation rates of haploid coleoptile section callus derived from 20 hybrids.

\begin{tabular}{|c|c|c|c|c|c|c|c|c|c|}
\hline \multirow[t]{2}{*}{ Group } & \multirow[t]{2}{*}{ Combination } & \multirow{2}{*}{$\begin{array}{c}\text { No. of } \\
\text { explants }\end{array}$} & \multirow{2}{*}{$\begin{array}{l}\text { No. of } \\
\text { callus }\end{array}$} & \multirow{2}{*}{$\begin{array}{l}\text { Induction } \\
\text { rate (\%) }\end{array}$} & \multirow{2}{*}{$\begin{array}{c}\text { Average } \\
\text { induction rate }\end{array}$} & \multicolumn{2}{|c|}{ No. of regenerated plants } & \multirow{2}{*}{$\begin{array}{c}\text { Differentiation } \\
\text { rate }(\%)\end{array}$} & \multirow{2}{*}{$\begin{array}{c}\text { Average } \\
\text { differentiation rate }\end{array}$} \\
\hline & & & & & & Total plants & Survive plants & & \\
\hline \multirow[t]{8}{*}{ Reid group } & C8605-2/Zheng58 & 86 & 33 & 38.4 & $41.55^{\star \star}$ & 0 & 0 & 0 & 4.65 \\
\hline & Zheng58/7922 & 122 & 49 & 40.2 & & 0 & 0 & 0 & \\
\hline & X73/Zheng58 & 106 & 44 & 41.5 & & 2 & 0 & 4.5 & \\
\hline & Shen5003/1216 & 110 & 36 & 32.7 & & 4 & 2 & 111 & \\
\hline & Shen5003/9137 & 82 & 41 & 50.0 & & 3 & 0 & 7.3 & \\
\hline & Zheng58/B73 & 82 & 63 & 76.8 & & 9 & 6 & 14.8 & \\
\hline & Shen5003/Dan9046 & 74 & 15 & 20.3 & & 0 & 0 & 0 & \\
\hline & C8065-2/Liao8160 & 80 & 26 & 32.5 & & 0 & 0 & 0 & \\
\hline \multirow[t]{6}{*}{ Tangsipingtou } & $444 / 482$ & 88 & 32 & 36.4 & $39.37^{* *}$ & 0 & 0 & 0 & 3.07 \\
\hline & Chang7-2/Dan5026, & 100 & 46 & 46.0 & & 3 & 2 & 6.5 & \\
\hline & Ji854/Chang7-2 & 90 & 59 & 65.6 & & 7 & 5 & 11.9 & \\
\hline & Ji853/LX9801 & 76 & 21 & 27.6 & & 0 & 0 & 0 & \\
\hline & Ji853/Hangzao4 & 66 & 18 & 27.3 & & 0 & 0 & 0 & \\
\hline & 482/Chang7-2 & 90 & 30 & 33.3 & & 0 & 0 & 0 & \\
\hline \multirow[t]{6}{*}{ Term-tropical } & P178/Dan599 & 114 & 17 & 14.9 & $17.25^{\star}$ & 0 & 0 & 0 & 0.00 \\
\hline & Shen137/Dan599 & 98 & 31 & 31.6 & & 0 & 0 & 0 & \\
\hline & Qi319/Dan599 & 106 & 18 & 17.0 & & 0 & 0 & 0 & \\
\hline & P178/Dan988 & 66 & 10 & 15.2 & & 0 & 0 & 0 & \\
\hline & P178/Qi319 & 82 & 13 & 15.9 & & 0 & 0 & 0 & \\
\hline & Shen137/P178 & 90 & 8 & 8.9 & & 0 & 0 & 0 & \\
\hline
\end{tabular}

*and **indicate significant differences at 0.05 and 0.01 levels, respectively.

\section{Chromosome number in regenerated plants and identification of pollen fertility}

Root tip cells of all the 15 regenerated plants contained 10 chromosomes each (Figure 1B), indicating that these plants were haploid. Microscopic examination of pollen from the regenerated plants revealed that 9 male flowers had completely sterile pollen, while 6 had partially pollinated anthers (Figure 1C) with a fraction of pollen that was fertile (stained with I-KI)and the other that was sterile (not stained with I-KI; Figure 1D). These observations suggested that only a part of pollen grains in the pollinated anther were successfully doubled. 

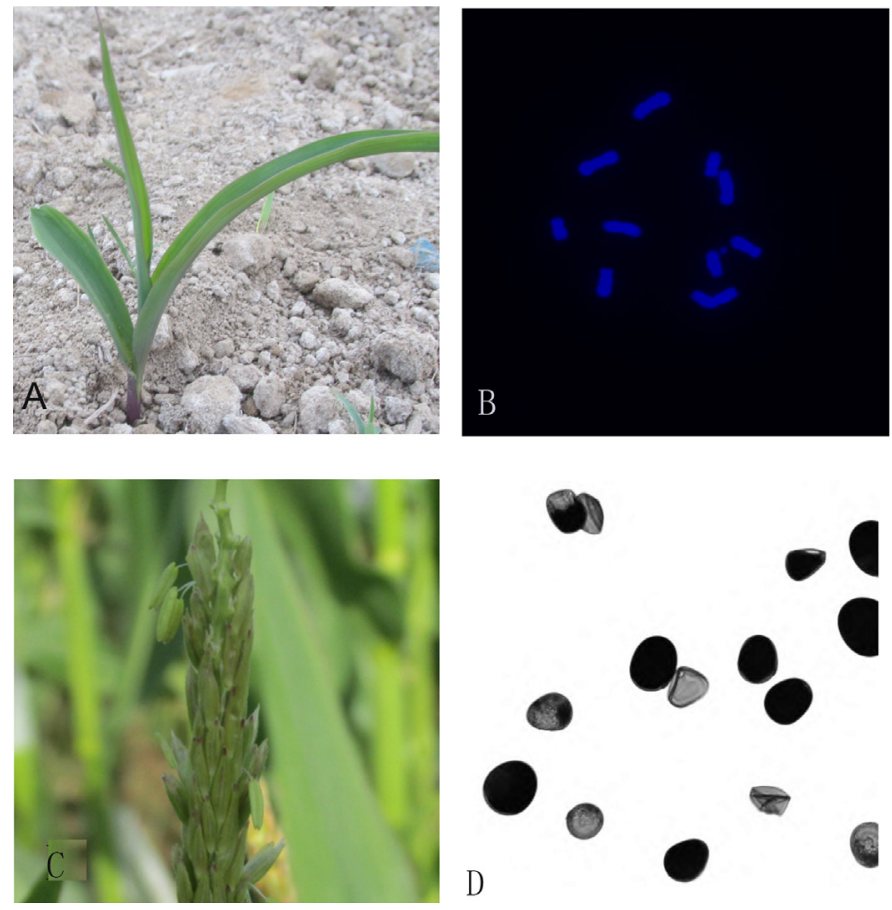

Figure 1. Identification of chromosome number and pollen fertility of regenerated plants: regenerated plant (A), shedding anther (B), partial fertile pollen (C), chromosome number in root tip cells of regenerated plants (D).

\section{Genotypic analysis of regenerated haploid plants}

Analysis of diversity in haploid parents with SSR markers indicated that the genotypes of haploid plants were all from parents' recombinant types. The number of polymorphic sites detected in Zheng58 and B73, Shen5003 and 1216, Ji854 and Chang7-2, Chang7-2 and Dan5026 were 29, 21, 16, and 14, respectively. Polymorphic SSR markers were further used to detect the genotypes of the regenerated plants. The results obtained revealed the following: 6-10 sites in 6 haploid plants with genetic background of Zheng58/B73 came from Zheng58, while 19-23 sites came from B73; in 2 haploid plants with the genetic background of Shen5003/1216, 9 and 8 sites were from Shen5003, while 12 and 13 sites were from 1216, respectively; 4-12 sites in haploid materials of Ji854/Chang7-2 were the same with Ji854, while 4-12 sites were the same with Chang7-2; in 2 haploid plants with the background of Chang7-2/ Dan5026, 6 and 5 sites came from Chang7-2, while 8 and 9 sites came from Dan5026, respectively. The coefficients for genetic similarity of the 6 haploid plants with Zheng58/B73 background to B73 were above 0.80 , while those for similarity to Zheng58 were lower than 0.6 and showed distorted segregation (Table 4).

As is evident from the analysis in Figure 2, SSR banding patterns of the detected polymorphic sites in 15 haploid plants were identical to male or female parents of hybrids, and no hybrid or missing banding patterns were observed, indicating that the regenerated haploid plants did not have somaclonal variation and were genetically stable. 


\begin{tabular}{|c|c|c|c|c|c|}
\hline \multirow[t]{2}{*}{ Combinations } & \multirow[t]{2}{*}{ No. } & \multicolumn{2}{|c|}{ Polymorphic SSR makers } & \multicolumn{2}{|c|}{ Genetic similarity coefficients (\%) } \\
\hline & & P1 & P2 & P1 & P2 \\
\hline \multirow[t]{6}{*}{ Zheng58/B73 } & 1 & 6 & 23 & 51.06 & 87.23 \\
\hline & 2 & 9 & 20 & 57.45 & 80.85 \\
\hline & 3 & 6 & 23 & 51.06 & 87.23 \\
\hline & 4 & 10 & 19 & 59.57 & 78.72 \\
\hline & 5 & 8 & 21 & 55.19 & 82.98 \\
\hline & 6 & 8 & 21 & 55.32 & 82.98 \\
\hline \multirow[t]{2}{*}{ Shen5003/1216 } & 1 & 9 & 12 & 74.47 & 80.85 \\
\hline & 2 & 8 & 13 & 72.34 & 82.98 \\
\hline \multirow[t]{5}{*}{ Ji854/Chang7-2 } & 1 & 10 & 6 & 87.23 & 78.72 \\
\hline & 2 & 6 & 10 & 78.72 & 87.23 \\
\hline & 3 & 5 & 11 & 76.60 & 89.36 \\
\hline & 4 & 12 & 4 & 91.49 & 74.47 \\
\hline & 5 & 4 & 12 & 74.47 & 91.49 \\
\hline \multirow[t]{2}{*}{ Chang7-2/Dan5026 } & 1 & 6 & 8 & 82.98 & 87.23 \\
\hline & 2 & 5 & 9 & 80.85 & 89.36 \\
\hline
\end{tabular}

P1 - female, P2 - male.

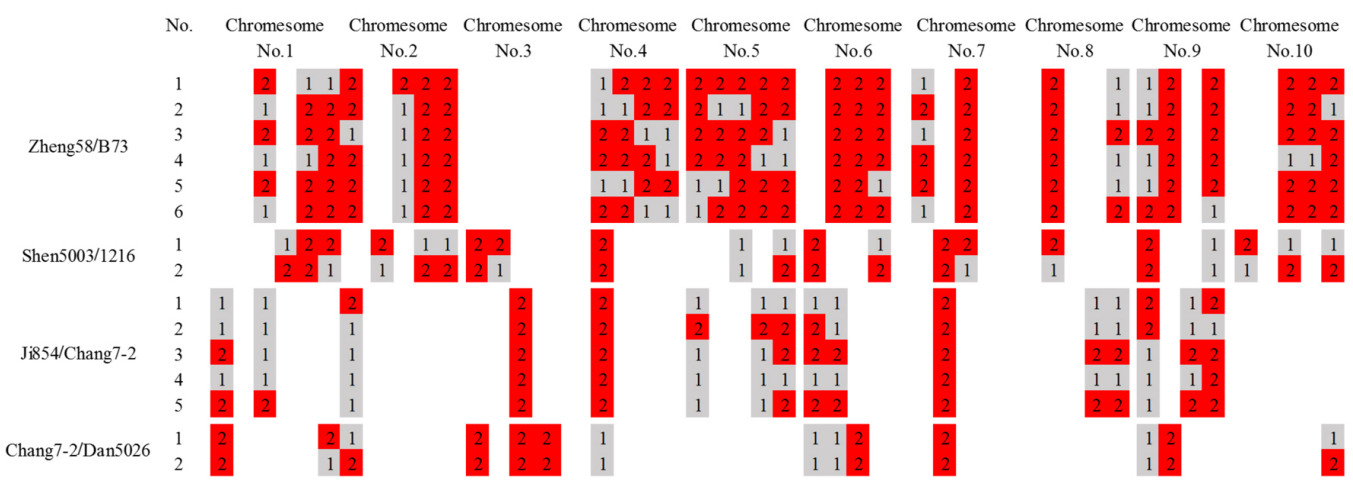

Figure 2. Genotypic analysis of 15 haploid plants: P1 - maternal chromosome segment, P2 - paternal chromosome segment.

\section{DISCUSSION}

\section{Influence of genotypes on coleoptile section haploid callus culture}

Induction of callus from young embryos in maize is affected by the genotype, while that of type-II callus is confined to a few genotypes including A188, B73, and Hi-II (Songstad et al., 1991; Bronsema et al., 1997; Vega et al., 2008). There is a great difference among maize materials of different heterotic groups in terms of callus induction and differentiation rate, and so it is among different genotypes in the same heterotic group. Zhang et al. (2004) studied 19 inbred lines in 3 heterotic groups including Reid, Tangsipingtou, and another germplasm and observed that Huangye4, Jing24, and Ji853 in 4 inbred line materials of Tangsipingtou group had poor differentiation ability and could not regenerate, while Huangzao4 green plantlet differentiation rate was only $0.5 \%$. Guo et al. (2007) studied 19 inbred lines of 5 heterotic groups, and reported that young embryos of inbred lines in Reid group had good tissue culture characteristics and 
B73, HuangC, and 478 had high young embryo callus induction rates and thus could be useful in genetic transformation as acceptor materials. In their study, no materials with good tissue culture characteristics were screened in Lancaster and Tangsipingtou groups. This study revealed that induction and differentiation of haploid coleoptile section callus were greatly affected by genotypes, and that Reid and Tangsipingtou groups had better induction and differentiation than Term-tropical group. Zheng58/B73 in the Reid group had high induction and differentiation rate, which was consistent with the results obtained in diploid maize (Zhang et al., 2004; Guo et al., 2007) signifying that B73 had good tissue culture characteristics. Ji854/Chang7-2 in Tangsipingtou group had high induction rate, and its differentiated regenerated plants were good acceptor materials. However, Ji853/LX9801 and Ji853/Huangzao4 had low induction rates, and could not differentiate into regenerated plants. This might have been caused by poor tissue culture characteristics of Ji853 and Huangzao4, as was also reported by Zhang et al. (2004). Six materials in the Term-tropical group had poor tissue culture characteristics and low callus induction rate, and did not differentiate into regenerated plants, probably because of their unsuitability for tissue culture.

In this study, 884 haploid coleoptile sections were inoculated, but only 15 haploid plants differentiated and 6 tassels were pollinated. Not many haploid plants differentiated from each explants, because induction and differentiation of haploid coleoptile section callus were greatly influenced by genotypes. Thus, future research should also focus on improving induction and differentiation culture media and enhancing induction and differentiation rates of haploid coleoptile section callus.

\section{Utilization of tissue culture of haploid coleoptile sections in maize breeding}

Quick and massive acquisition of maize DH lines can shorten the breeding cycle and improve breeding efficiency. Inducer lines from the Stock6 had haploid induction rates generally between 2 and 8\%, and some were above 10\% (Eder and Chalyk, 2002; Li et al., 2009; Zhao et al., 2013). It is quite easy to obtain coleoptile sections through germination of haploid grains without any influence of season; coleoptile sections are thus a kind of fine explants. In this study, the mean induction rates of haploid callus in Reid, Tangsipingtou, and Term-tropical groups were determined to be $40.24,37.85$, and $15.13 \%$, respectively, which were far higher than those obtained in anther and microspore culture (Szarka et al., 2001; Jäger et al., 2005), thereby favoring haploid callus formation. Zhao et al. (2007) treated young haploid embryos or the callus with herbicide that improved the doubling efficiency. Gordon-kamm et al. (2007) treated young haploid embryos with herbicide and doubled haploid stem tip successfully. Haploid young embryos are influenced by season, and this study demonstrated that it was very difficult to distinguish the size of young haploid and diploid embryos and such judgments were often inaccurate. Although haploid stem-tip tissues are fine explants un-influenced by season, it is difficult to peel the stem tip off, and thereby breeding requirements can hardly be met. It is very convenient to obtain haploid coleoptile sections, and some genotypes have high callus induction and differentiation rates. Maize haploid callus treated with certain concentration of colchicine or herbicide solution, differentiated and regenerated, and then double haploid plants were obtained (Petersen et al., 2003). Therefore, doubling of haploid callus or regenerated plants based on further improvements in induction and differentiation rate of haploid coleoptile section callus could be one of the effective ways to improve maize haploid doubling efficiency and to obtain $\mathrm{DH}$ lines.

Reid and Tangsipingtou maize groups had high induction rates for haploid coleoptile section callus, and differentiated into 8 and 7 haploid plants respectively while the Term-tropical group had low haploid callus induction rate and could not differentiate into haploid plants. To the 
best of our knowledge, this is the first study that used haploid stem nodes as explants for obtaining maize haploid plants through tissue culture.

\section{Conflicts of interest}

The authors declare no conflict of interest.

\section{ACKNOWLEDGMENTS}

Research supported by funds from the National Spark Plan Project (\#2012AA10A305) and the Chinese Universities Scientific Fund (\#15053201). The authors greatly appreciate the helpful comments and suggestions from Dr. Zhang Xinliang and other anonymous reviewers.

\section{REFERENCES}

Barnabas B, Obert B and Kovacs G (1999). Colchicine, an efficient genome-doubling agent for maize (Zea mays L.) microspores cultured in anthero. Plant Cell Rep. 18: 858-862.

Baron JE, Maddock SE, Wu XE, Zhao ZY, et al. (2014). Doubling of chromosomes in haploid embryos. Unit. Stat. Pat. 8859846. Bronsema FBF, van Oostveen WJF and van Lammeren AAM (1997). Comparative analysis of callus formation and regeneration on cultured immature maize embryos of the inbred lines A188 and A632. Plant Cell Tiss. Org. 50: 57-65.

Cai Z, Xu GL, Liu XH, Dong YL, et al. (2007). The breeding of JAAS3-haploid inducer with high frequency parthenogenesis in maize. J. Maize Sci. 15: 1-4.

Chase SS (1952). Production of homozygous diploids of maize from monoploids. Agron. J. 44: 263-267.

Eder J and Chalyk S (2002). In vivo haploid induction in maize. Theor. Appl. Genet. 104: 703-708.

Gallais A and Bordes J ( 2007). The use of doubled haploids in recurrent selection and hybrid development in maize. Crop Sci. 47: 190-201.

Geiger HH and Gordillo GA (2009). Double haploids in hybrid maize breeding. Maydica 54: 485-499.

Guo XM, Zhang XD, Han LX and Chen YF (2007). Characteristic of callus induced from immature embryo among different maize inbreds. J. North. A\&F Univ. Nat. Sci. Ed. 35.

Hallauer AR, Carena MJ and Miranda Filho JB (2010). Quantitative genetics in maize breeding. Springer Science and Business Media, LLC, New York, NY.

Han XL, Tang QL and Rong TZ (2009). Study on doubling efficiency of maize haploid induced by Stock6. J. Maize Sci. 17: 22-27. Häntzschel KR and Weber G (2010). Blockage of mitosis in maize root tips using colchicine-alternatives. Protoplasma 241: 99-104.

Jäger K, Köszegi D and Barnabás B (2005). Regeneration capacity of microspore-derived structures in anther cultures of maize (Zea mays L.). Acta Physiol. Plant. 27: 621-629.

Jiang L, Ci JB, Cui XY, Zhang Y, et al. (2014). Study on induction rate and doubling rate of maize haploid under different ecological conditions. J. Jilin Agric. Univ. 2.

Kato A and Geiger $\mathrm{HH}$ (2002). Chromosome doubling of haploid maize seedlings using nitrous oxide gas at the flower primordial stage. Plant Breed. 121: 370-377.

Li L, Xu X, Jin W and Chen S (2009). Morphological and molecular evidences for DNA introgression in haploid induction via a high oil inducer CAUHOI in maize. Planta 230: 367-376

Martin M, Miedaner T, Dhillon BS, Ufermann U, et al. (2011). Colocalization of QTL for Gibberella ear rot resistance and low mycotoxin contamination in early European maize. Crop Sci. 51: 1935-1945.

Petersen KK, Hagberg P and Kristiansen K (2003). Colchicine and oryzalin mediated chromosome doubling in different genotypes of Miscanthus sinensis. Plant Cell Tiss. Org. 73: 137-146.

Pixley K and Banziger M (2004). Open-pollinated maize varieties: a backward step or valuable option for farmers? In: Integrated Approaches to Higher Maize Productivity in the new Millennium: Proceedings of the 7th Eastern and Southern Africa Regional Maize Conference (Friesen DK and Palmer AFE, eds.). Nairobi, Kenya, 22-28.

Presterl T, Ouzunova M, Schmidt W, Möller EM, et al. (2007). Quantitative trait loci for early plant vigour of maize grown in chilly environments. Theor. Appl. Genet. 114: 1059-1107.

Röber FK, Gordillo GA and Geiger HH (2005). In vivo haploid induction in maize-performance of new inducers and significance of doubled haploid lines in hybrid breeding. Maydica 50: 275-283. 
Saghai-Maroof MA, Soliman KM, Jorgenson RA and Allard RW (1984). Ribosomal DNA spacer-length polymorphisms in barley: Mendelian inheritance, chromosomal location and population dynamics. Proc. Natl. Acad. Sci. USA. 81: 8014-8018.

Sidorov V, Gilbertson L, Addae P and Ducan D (2006). Agrobacterium-mediated transformation of seedling-derived maize callus. Plant Cell Rep. 25: 320-328.

Songstad DD, Armstrong CL and Petersen WL (1991). $\mathrm{AgNO}_{3}$ increases typell callus production from immature embryos of maize inbred B73 and its derivatives. Plant Cell Rep. 9: 699-702.

Soriano M, Cistué L, Vallés MP and Castillo AM (2007). Effects of colchicine on anther and microspore culture of bread wheat (Triticum aestivum L.). Plant Cell Tiss. Org. 91: 225-234.

Szarka B, Dévényi M and Mórocz S (2001). Fertile maize lines obtained from isolated microspores. Euphytica 122: 53-60.

Vega JM, Yu WC, Kennon AR, Chen XL, et al. (2008). Improvement of Agrobacterium-mediated transformation in Hi-II maize (Zea mays) using standard binary vectors. Plant Cell Rep. 27: 297-305.

Wilde K, Burger H, Prigge V, Presterl T, et al. (2010). Testcross performance of doubled-haploid lines developed from European flint maize landraces. Plant Breed. 129: 181-185.

Wu PH, Ren JJ, Li L and Chen SJ (2014). Early spontaneous diploidization of maternal maize haploids generated by in vivo haploid induction. Euphytica 200: 127-138.

Zhang HM, Liu XH, Zhang HW, Liu XJ, et al. (2004). Characterization of callus induction and plant regeneration in immature embryo culture among several heterotic groups of elite maize inbreds. Acta Bot. Boreal.-Occident. Sin. 24: 50-55.

Zhao X, Xu X, Xie H, Chen S, et al. (2013). Fertilization and uniparental chromosome elimination during crosses with maize haploid inducers. Plant Physiol. 163: 721-731.

Zhao ZY, Bidner DL, Elsing ED, Miller MD, et al. (2006). Doubled haploid cells, embryos and plants. United States Patent Application 20060185033. 